\title{
A Glioblastoma Multiforme Case Spread to Lomber Spine
}

\section{Lomber Omurgaya Yayılan Bir Glioblastoma Multiforme Olgusu}

\author{
Selçuk Cemil Öztürk ${ }^{1}$, Gülnihal Tufan ${ }^{2}$, Mustafa Benekli $^{3}$, Nedim Turan ${ }^{4}$ \\ ${ }^{1}$ Medline Antalya Hastanesi, Trbbi Onkoloji, Antalya, Türkiye \\ ${ }^{2}$ Rize Eğitim ve Araştırma Hastanesi, Tıbbi Onkoloji, Rize, Türkiye \\ ${ }^{3}$ Gazi Üniversitesi Tıp Fakültesi, Tıbbi Onkoloji Bilim Dalı, Ankara, Türkiye \\ DOI: 10.5505/aot.2011.42714 \\ ${ }^{4}$ Cumhuriyet Üniversitesi Tıp Fakültesi, Tıbbi Onkoloji Bilim Dalı, Sivas, Türkiye
}

\section{ÖZET}

Glioblastoma multiformenin (GBM) serebrospinal sıv1 aracılığı ile omurgaya metastazı sık görülen bir durum değildir. Biz burada cerrahi ve kemoradyoterapi ile lokal tedavisinden sonra omurgaya metastaz yapan bir intrakranial GBM olgusunu sunduk. Hasta kranial GBM ile ilk gelişinden bir yıl sonra bel ağrısı ve alt ekstremitelerde güçsüzlükle başvurdu. Lomber magnetik rezonans görüntüleme incelemesinde L1'de intradural kitle izlendi. Yapılan eksizyonel biyopside GBM gösterildi.

Anahtar Kelimeler: Glioblastoma multiforme; Metastaz; Omurga

\section{ABSTRACT}

The metastasis of glioblastoma multiforme (GBM) to spine via cerebrospinal fluid is not a common case. We presented an intracranial GBM case metastasized to spine after local treatment of cranial lesion with surgery and chemoradiotherapy. Patient admitted with low back pain and lower limb weakness one year after the diagnosis of cranial GBM. Lumbar magnetic resonance imaging demonstrated intradural mass at the level of L1. Pathology of the excisional biopsy showed GBM.

Key words: Glioblastoma multiforme; Metastasis; Spine.

\section{Introduction}

Glioblastoma Multiforme (GBM) is the most common primary malignant brain tumor. Extracranial metastasis of GBM is rare. It can metastasize to the spinal cord via cerebrospinal fluid (CSF) (1,2). The incidence of spinal metastasis of GBM through CSF is not known exactly. Our patient presented with symptomatic L1 radiculopathy after treatment of GBM without local recurrence.

\section{Case Report}

A 61 year-old-man presented with history of headache and dizziness for 5 months in March 2009. Cranial magnetic resonance imaging (MRI) showed right temporal, parahypocampal lesions of which the largest was $4.5 \mathrm{~cm}$ in diameter with peripheral edematous area (Figure 1).

Right frontotemporal craniotomy and gross total excision were performed. Pathological examination revealed GBM (World Health Organization [WHO] grade IV). After surgical excision, cranial radiotherapy
(RT) concurrent with temozolamide was applied. Totally 60 Gy RT daily fractions of 2 Gy, 5 days per week for 6 weeks, and concurrent daily oral temozolamide, $75 \mathrm{mg} / \mathrm{m}^{2}$ per day, 7 days per week.

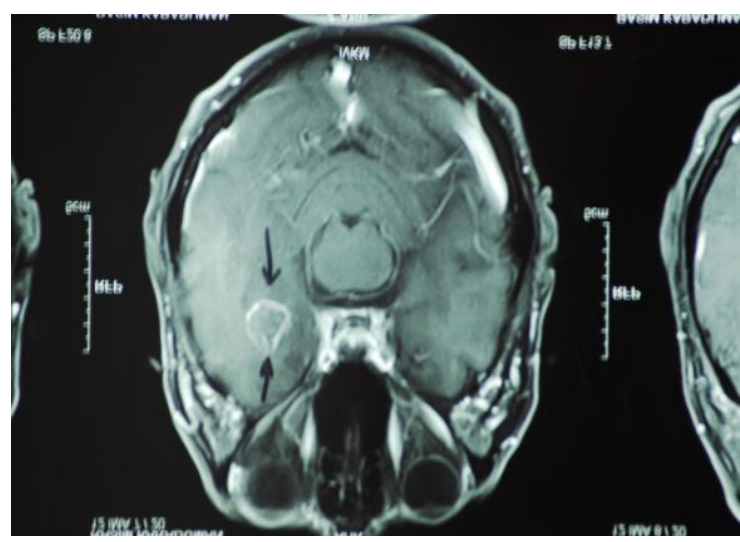

Figure 1: T1-weighted image showing an iso- to hypointense mass in the spinal cord. Preoperative gadolinium-enhanced T1-weighted axial MRI scan revealing a dominant lesion located in the left temporal lobe, demonstrating ring enhancement. Axial T1 weighted contrast enhanced MRI image 
demonstrating ring-enhanced lesion of the left temporal lobe.

Three weeks after the chemoradiotherapy was completed, temozolamide $150 \mathrm{mg} / \mathrm{m}^{2}$ for 5 days during each 28-day cycle was started. He had 6 cycles of temozolamide.

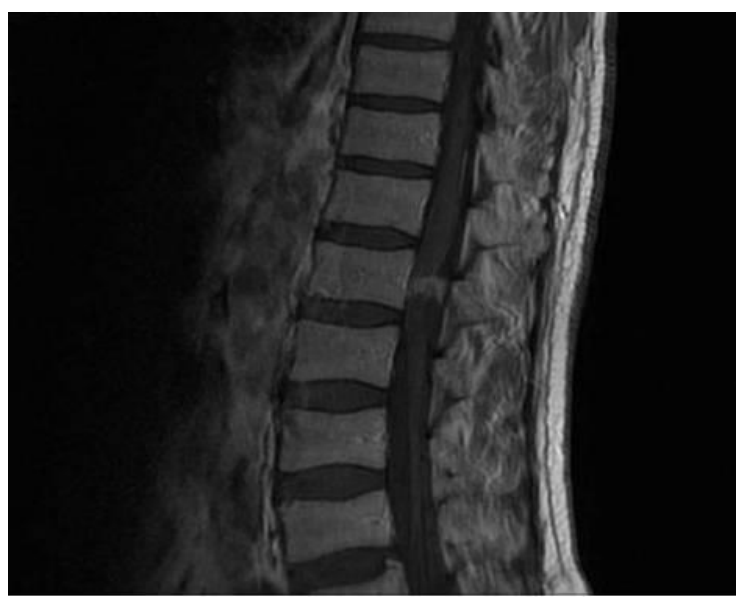

Figure 2: T1-weighted image showing an iso- to hypointense mass in the spinal cord. Preoperative gadolinium-enhanced T1-weighted axial MRI scan revealing a dominant lesion located in the left temporal lobe, demonstrating ring enhancement.

Until April 2010, he had been followed without recurrence. In April 2010, he was admitted to the hospital with low back pain and right lower limb weakness. Spine MRI showed an extramedullary-intradural mass, measuring $38 \times 18 \times 13 \mathrm{~mm}$ in diameter (Figure 2). Medullary channel was filled fully with this mass and caudal fibers and conus medullaris were compressed. In May 2010, excisional biopsy was performed. Pathologic examination showed GBM, WHO grade IV (Figure 3). Cranial MRI demonstrated no new or recurrent lesion. Focal RT and concurrent temozolamide were performed.

\section{Discussion}

We know that intracranial malign gliomas can metastasize via leptomeningeal spreading. Until 2010, totally 45 cases with intracranial GBM metastasized to spine were reported $(1,2)$. Leptomeningeal spreading occurs in 15 to $25 \%$ of cases of supratentorial GBM, up to $60 \%$ for infratentorial GBM. In a study of 600 patients with GBM, only $2 \%$ had symptomatic CSF seeding (3). The most common sites in spine are the lower thoracic, upper lumbar and lumbosacral regions.

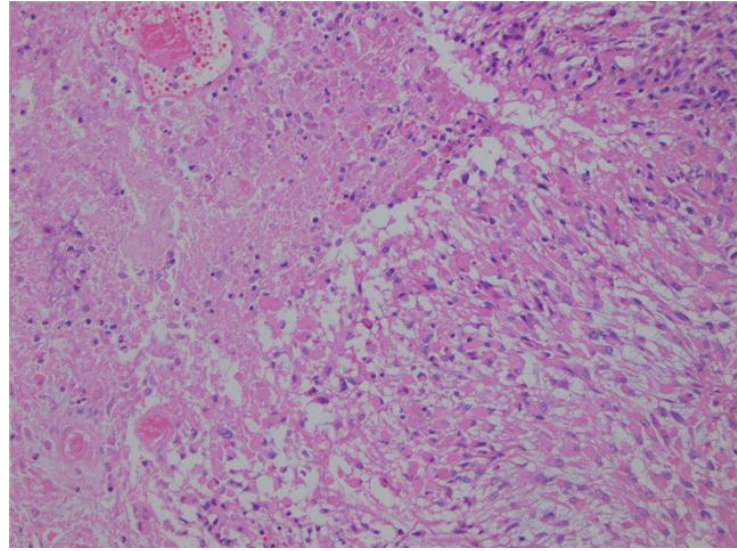

Figure 3: Highly cellular tumor tissue was composed of neoplastic astrocytic cells and microvascular proliferation was present (H\&E, x200).

Intramedullary metastases are rare (3-5). The mechanism of spread is leptomeningeal invasion of basement membrane structures, with subependymal growth and invasion of the choroid plexus, eventually leading to metastatic spread along CSF (6). Malignant tumor cells can penetrate from perivascular area to subarachnoid space. The most common clinical symptoms of leptomeningeal metastasis of GBM are radicular pain in limbs, low back, interscapular area, and neck (4).

There are no spesific treatment modalities for leptomeningeal metastasis. Surgical decompression allows for confirmation of the diagnosis and may be helpful for pain control and palliation. Cytoreductive debulking of a large metastatic deposit may be an important adjunct to RT and chemotherapy (4). Treatment modalities that have been designed to prevent leptomeningeal dissemination should be part of the primary management of high risk patients. One option is stereotactic biopsy with cranial RT and delayed open tumor resection. The prognosis of patient who has leptomeningeal metastasis is very poor. CSF tumor dissemination almost always has a fatal outcome (7). Median time from diagnosis of the primary GBM to diagnosis of CSF tumor dissemination ranges from 8 to 14 months, median overall survival ranges from 11 to 17 months, and the average time interval between diagnosis of leptomeningeal metastasis and death is 2 to 3 months (7-9). We present a case of GBM metastatic to the spinal cord with stable intracranial disease after adjuvant treatment.

\section{Conflict of Interest: None}




\section{References}

1. Hübner F, Braun V, Richter HP. Case Report of Symptomatic metastases in four patients with primary intracranial gliomas. Acta Neurochir (Wien) 2001;143:25-9

2. Birbilis TA, Matis GK, Eleftheriadis SG, Theodoropoulou EN, Sivridis E. Spinal metastasis of glioblastoma multiforme: an uncommon suspect? Spine (Phila Pa 1976) 2010;35:264-9

3. Karaca M, Andrieu MN, Hicsonmez A, et al. Cases of glioblastoma multiforme metastasing to spinal cord. Neurol India 2006;54:428-30.

4. Giese A,Westphal M. Glioma invasion in the central nervous system. Neurosurgery 1996;39:235-52

5. Stanley P, Senac MO Jr, Segall HD. Intraspinal seeding from intracranial tumors in children. Am J Roentgenol 1985;144:157-61
6. Mihara F, Ikeda M, Rothman MI, Numaguchi Y, Kristt D. Vertebral body metastasis of glioblastoma multiforme with epidural mass formation. Contrastmediated MRI study. Clin Imaging 1994;18:386-9

7. Alatakis S, Malhalm G, Thien C. Spinal leptomeningeal metastasis from cerebral glioblastoma multiforme presenting with radicular pain: Case report and literature review. Surgical Neurology 2001;56:33-7

8. Grabb PA, Albright AL, Pang D. Dissemination of supratentorial malignant gliomas via the cerebrospinal fluid in children. Neurosurgery 1992:30:64-71

9. Vertosick FT, Selker RG. Brainstem and spinal metastases of supratentorial glioblastoma multiforme: a clinical series. Neurosurgery 1990;27:516-22 